\title{
Stream biogeochemical and suspended sediment responses to permafrost degradation in stream banks in Taylor Valley, Antarctica
}

\author{
Michael N. Gooseff ${ }^{1}$, David Van Horn ${ }^{2}$, Zachary Sudman ${ }^{3}$, Diane M. McKnight ${ }^{1}$, Kathleene A. Welch ${ }^{4}$, and \\ William B. Lyons ${ }^{4}$ \\ ${ }^{1}$ Institute of Arctic and Alpine Research, University of Colorado, Boulder, Colorado, USA \\ ${ }^{2}$ Department of Biology, University of New Mexico, Albuquerque, New Mexico, USA \\ ${ }^{3}$ Department of Civil \& Environmental Engineering, Colorado State University, Fort Collins, CO, USA \\ ${ }^{4}$ School of Earth Sciences, The Ohio State University, Columbus, Ohio, USA
}

Correspondence to: Michael N. Gooseff (michael.gooseff@colorado.edu)

Received: 30 June 2015 - Published in Biogeosciences Discuss.: 8 September 2015

Revised: 3 February 2016 - Accepted: 17 February 2016 - Published: 21 March 2016

\begin{abstract}
Stream channels in the McMurdo Dry Valleys are characteristically wide, incised, and stable. At typical flows, streams occupy a fraction of the oversized channels, providing habitat for algal mats. In January 2012, we discovered substantial channel erosion and subsurface thermomechanical erosion undercutting banks of the Crescent Stream. We sampled stream water along the impacted reach and compared concentrations of solutes to the long-term data from this stream ( $\sim 20$ years of monitoring). Thermokarstimpacted stream water demonstrated higher electrical conductivity, and concentrations of chloride, sulfate, sodium, and nitrate than the long-term medians. These results suggest that this mode of lateral permafrost degradation may substantially impact stream solute loads and potentially fertilize stream and lake ecosystems. The potential for sediment to scour or bury stream algal mats is yet to be determined, though it may offset impacts of associated increased nutrient loads to streams.
\end{abstract}

\section{Introduction}

General circulation models predict a disproportionate increase in high-latitude air temperatures over the next century due to polar amplification mechanisms (Serreze and Barry, 2011a, b; Bekryaev et al., 2010). A potential consequence of increasing polar air temperatures is increased ground sur- face energy balance, and accelerated permafrost degradation (Chadburn et al., 2015) including surface subsidence, thermokarst formation, and mass wasting of the landscape, with significant implications for adjacent aquatic ecosystems. A growing body of literature has documented varying impacts of permafrost degradation on streams and lakes, with a primary focus on Arctic tundra landscapes. When degradation occurs at large scales or is hydrologically well connected to associated aquatic ecosystems, order-of-magnitude increases of sediment, solute, and nutrient loads to streams and lakes are common (Kokelj et al., 2005, 2009, 2013; Larouche et al., 2015; Bowden et al., 2008). Under these conditions impact can persist for decades (Kokelj et al., 2005, 2009). In contrast, when hydrologic connectivity linking degraded permafrost to aquatic systems is limited, or a small portion of a catchment is affected, the impacts to associated aquatic ecosystems are reduced and transient (Lafrenière and Lamoureux, 2013; Lewis et al., 2012; Larouche et al., 2015; Lamoureux and Lafrenière, 2009).

Permafrost degradation has received much less attention in polar desert environments, which are common in Antarctica and also occur in the Arctic. One potential mode of permafrost degradation is from enhanced flow of water across hillslopes (i.e., non-channelized flow). Polar deserts receive little to no rainfall and therefore have less potential for permafrost degradation to be associated with shallow subsurface or overland flow outside of stream channels. There is some 


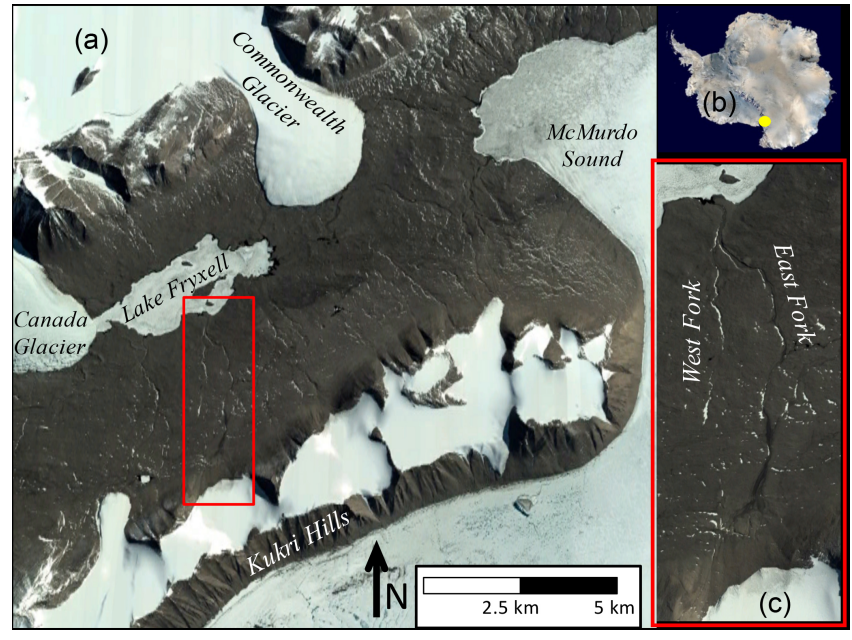

Figure 1. Map of (a) the location of the McMurdo Dry Valleys in Antarctica, (b) the Lake Fryxell basin, in the eastern portion of Taylor Valley, with a red rectangle indicating Crescent Stream, and (c) a zoomed in view of the East and West Forks of the Crescent Stream.

evidence of ancient (Shaw and Healy, 1977) and centuriesold thermokarst activity (Healy, 1975; Campbell and Claridge, 2003) in Antarctic polar deserts, but there are limited examples of contemporary thermokarst features. The largest polar desert region in Antarctica is the McMurdo Dry Valleys (MDV), which occupy approximately $22700 \mathrm{~km}^{2}$ along the coast of McMurdo Sound, and contain the largest ice-free portion $\left(4500 \mathrm{~km}^{2}\right.$ ) of Antarctica (Levy, 2013). The MDV is underlain by continuous permafrost, much of which is poorly saturated frozen ground (i.e., < $10 \%$; Bockheim, 1995). Active layers (surface soils that are seasonally thawed) typically range 20-45 inland and $45-70 \mathrm{~cm}$ in coastal regions of the dry valley landscape (Bockheim et al., 2007), and as much as $85 \mathrm{~cm}$ in soils and sediments underneath and/or adjacent to streams and lakes (Northcott et al., 2009). Thus, this region is ideal for identifying and studying permafrost degradation in polar deserts which are typical of Antarctica. While the present MDV landscape is generally considered to be geomorphically stable, a recent study documented contemporary thermokarst activity associated with thawing of a massive ice feature in Garwood Valley, likely made up of Pleistocene age water (Levy et al., 2013). The estimated current rate of thaw (exposed massive ice cliff changes of $2-4 \mathrm{~cm} \mathrm{day}^{-1}$ ) exceeds previous rates by an order of magnitude and has been linked to increased insolation occurring in this region (Levy et al., 2013; Fountain et al., 2014). This rapid response to increased insolation suggests that permafrost in Antarctica is susceptible to changing conditions including predicted future warming (Swanger and Marchant, 2007; Levy et al., 2013), however, there is little indication of how these disturbances may impact receiving aquatic ecosystems.

The streams and lakes in the MDV have unique characteristics that will likely affect their responses to, and the im- pacts of, permafrost degradation. Stream flow in the MDV originates from melt water emanating from alpine, piedmont, and terminal glaciers. Glacial melt occurs for up to 10 weeks during the austral summer (McKnight et al., 1999) with significant diurnal, monthly, and inter-annual variability driven by varying sun angle, insolation (McKnight et al., 1999) and air temperature (Doran et al., 2008). Thus the hydrographs in these streams are dynamic, with streamflow typically varying two to ten-fold on a diel basis for example. Once melt water enters stream channels it interacts with surrounding sediments through hyporheic exchange (Runkel et al., 1998; Gooseff et al., 2003) which alters stream chemistry (Gooseff et al., 2002; Welch et al., 2010; McKnight et al., 2004). These streams support an assemblage of cyanobacteria, chemotrophic bacteria, and diatoms (Esposito et al., 2006; Stanish et al., 2013), and supply closed-basin (endorheic) lakes with water and solutes (Lyons et al., 1998; Green et al., 1988). Due to the geomorphic stability of the MDV over the past several thousand years, nutrient and solute loads derived from weathering processes occurring in the hyporheic zone (Gooseff et al., 2002) have likely been fairly constant. Thus, the potential introduction of nutrient pulses from stream-side thermokarst activity represents a new input that may significantly impact the nutrient status and biological communities of MDV streams and contribute to downstream closed-basin lakes.

In January 2012 we found fresh permafrost degradation features along the channel margins of the West Fork of Crescent Stream in Taylor Valley, which is one of the central and most studied of the McMurdo Dry Valleys. Unlike the previously described dry valley thermokarst which resulted from the melting of buried ancient ice, these thermokarst features are contemporary examples of stream water interacting with and thawing extensive areas of permafrost soils adjacent to a stream channel. The goals of this study were to (1) describe the thermokarst as a basis for comparison for potential new thermokarst features in the MDV and other polar deserts in the future, (2) document the impacts of this permafrost degradation event on stream water sediment and solute concentrations and (3) compare these impacts to a long-term historical record. The impacts were evaluated by comparison of water quality above and below the thermokarst feature and by comparison of water quality of the impacted West Fork and the East Fork at their confluence.

\section{Site description}

The McMurdo Dry Valleys $\left(77^{\circ} \mathrm{S}, 162^{\circ} \mathrm{E}\right)$ comprise a polar desert landscape with glaciers, extensive exposed rock outcrops and soils, stream channels, and ice-covered lakes. Stream flow occurs 6-10 weeks per year and is $\sim 100 \%$ glacial meltwater. Stream channels are incised in some places up to $3 \mathrm{~m}$, and are typically 5-10 $\mathrm{m}$ wide. During typical diel low flows the streams are only a few centimeters deep and 


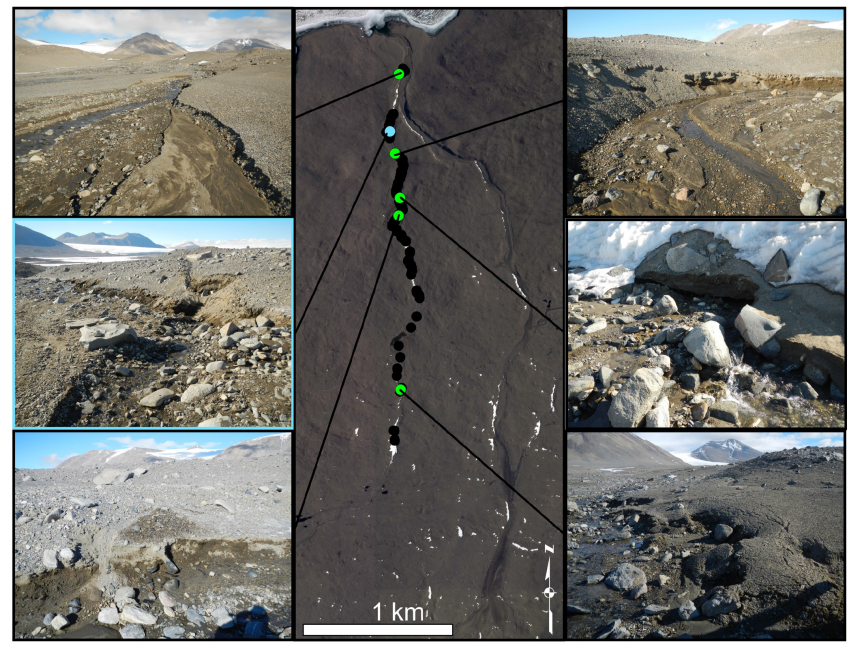

Figure 2. Map of images captured along the West Fork of Crescent Stream, as observed in January 2012, in which each black dot indicates a location at which a picture was taken, and the green dots indicate images from a few highlighted locations along the channel. Light blue highlighted image is of the entrance to the thermokarst tunnel on the east bank of the West Fork. Permafrost degradation features were observed along $+3 \mathrm{~km}$ of the West Fork of Crescent Stream. Remote-sensing image provided by the Polar Geospatial Center, University of Minnesota.

may occupy only half or less of the broader channel. Where streambeds have extensive desert pavement, the particularly stable substrate provides habitat for extensive algal mats and associated diatoms and chemotrophic bacterial communities (McKnight et al., 1999; Stanish et al., 2013). Stream length is an important control on solute concentrations. Because the primary source of water is glacial melt, longer streams interact with more sediments and therefore tend to have greater concentrations of solutes than shorter streams (McKnight et al., 2004; Lyons et al., 1998).

\section{Methods}

On 19 January 2012 we observed major down cutting, sediment deposition, and reworking of the stream channel at the long-term stream gauge site on Crescent Stream $\left(77.619064^{\circ} \mathrm{S}, 163.184464^{\circ} \mathrm{E}\right)$, near the mouth of the stream. We conducted an observational survey and photo documentation along $\sim 3 \mathrm{~km}$ of the West Fork of Crescent Stream to identify the source and extent of the disturbance and in the process found extensive slumping, undercutting, and tunnel development along the West Fork (Fig. 2). In one location, we observed a thermokarst tunnel of over $10 \mathrm{~m}$ in length cutting under the eastern bank of the channel. The East Fork showed no evidence of degradation.

On 21 January 2012, we conducted sampling to determine the impacts of the thermokarst-affected reach, and in particular the thermokarst tunnel, on stream water chemistry and sediment transport during a highly variable portion of the diurnal hydrograph (a doubling of discharge occurred during the sampling period). Prior to sampling, a Cutthroat Flume (Baski, Inc., Englewood, Colorado) was installed in an appropriate reach of the West Fork to monitor discharge throughout the sampling. At the beginning and end of the $4 \mathrm{~h}$ sampling we collected samples from the East and West Forks of Crescent Stream immediately upstream of the confluence and at the stream gauge location $\sim 200 \mathrm{~m}$ downstream of the confluence. During the collection we sampled the influent and effluent water from the thermokarst tunnel approximately every half hour to assess the impacts of thermokarst development in these polar desert streams.

During collection we measured water temperature and conductance of each sample with a YSI 30 (Yellow Springs Instruments Inc., Yellow Springs, Ohio). Samples for water chemistry were collected in ultra-pure water-rinsed HDPE bottles and were carried to the laboratory and filtered within $24 \mathrm{~h}$ of collection using $0.4 \mu \mathrm{m}$ pore size NucleporeTM polycarbonate membrane filters. Anion and $\mathrm{H}_{4} \mathrm{SiO}_{4}$ samples were filtered into ultra-pure water-rinsed HDPE bottles. $\mathrm{Nu}$ trient and cations samples were filtered into $\mathrm{HCl}$ and ultra pure water-rinsed HDPE bottles. Cation samples were preserved with acid to a $\mathrm{pH}$ of approximately $2-3$ by addition of $0.1 \%$ Ultrex nitric acid. Major ion and reactive Si samples were stored chilled at approximately $4^{\circ} \mathrm{C}$ until analysis. Nutrient samples were stored frozen until shortly before analysis.

Samples were analyzed for major anions and cations by ion chromatography using a Dionex DX-120 (Sunnyvale, CA) using methods described in Welch et al. (2010). $\mathrm{H}_{4} \mathrm{SiO}_{4}$ was determined using an automated colorimetric method based on the method of Mullin and Riley (1955) using the Skalar San ++ at Ohio State University. Nutrient analyses were done using a Lachat QuikChem 8000 FIA instrument (Loveland, CO). Total suspended solids (TSS) were measured by filtering $\sim 250 \mathrm{~mL}$ of stream onto tared, glass-fiber filters (Whatman GF/F) followed by drying at $60^{\circ} \mathrm{C}$ for $48 \mathrm{~h}$ to obtain dry weights $\left(\mathrm{mg} \mathrm{L}^{-1}\right)$.

A paired $t$ test was used to assess differences in solute concentrations for paired samples of water entering and exiting the thermokarst tunnel. A Welch's $t$ test, appropriate for sample populations with unequal sample sizes and variances, was used to compare the historic data to the data from the inflow and outflow of the thermokarst tunnel. The significance of p-values was assessed after applying a Bonferroni correction for the number of comparisons performed (in this case, $p<0.0056)$. All statistical analyses were performed in $\mathrm{R}(\mathrm{R}$ Development Core Team, 2011).

\section{Results}

As briefly described in the site description section, permafrost degradation along the banks of the West Fork of 
Crescent Stream was observed for over $3 \mathrm{~km}$ of stream reach (Fig. 2). The observation of substantial sediment deposition at the gauge site initiated the upstream survey of the channel. It was obvious that the channel had been re-worked by substantial flows in the recent days with clear downcutting (up to $20 \mathrm{~cm}$ ) in some sections and deposition of as much as $5 \mathrm{~cm}$ in low-gradient locations. Changes in sediment aggradation and degradation are the subject of other on-going studies of the field site, so we have chosen not to provide them here. Stream gauge records are insufficient to point to an exact moment that the sediment movement occurred at that location. Site visit notes indicate that the gauge was not in the observed condition even 7 days prior. The extent of degradation included many locations of undercutting of the banks on both sides of the channel. Frozen sediments within the banks provided enough cohesion that undercutting extended more than a meter laterally in some places, though the vertical gaps observed were on the order of $10-20 \mathrm{~cm}$. At some meander bends on either side of the broad channel, the stream cut further into the banks, widening the channel by $1 \mathrm{~m}$ or less in a few isolated places. This may have occurred due to bank erosion and subsequent slumping of up-gradient sediments. It is possible that undercutting occurred at these locations first, and then slumping of overburden. The cause of the degradation is not immediately obvious, but likely is the result of ponded water backed up at some point in the channel, perhaps behind snowdrifts that often form in the winter along the western banks. No obvious water lines from ponded water were observed upstream, though they may have been modified by the impacts to the banks. Flows were great enough to mobilize sediment, causing degradation in some places and aggradation in others.

\subsection{Thermokarst tunnel characteristics and impact}

During the sampling, discharged on the West Fork ranged from 1.19 to $2.04 \mathrm{~L} \mathrm{~s}^{-1}$. Effluent water from the thermokarst tunnel had significantly higher EC (mean of $327 \mu \mathrm{S} \mathrm{cm}^{-1}$; Table 1) and TSS $\left(402 \mathrm{mg} \mathrm{L}^{-1}\right)$ than influent water (means of $272 \mu \mathrm{S} \mathrm{cm}^{-1}$ and $9.56 \mathrm{mg} \mathrm{L}^{-1}$, respectively, Fig. 3). These increases in dissolved and suspended solids indicate that there was substantial change to the water flowing along this fairly short flow path. Influent waters also significantly increased concentrations of $\mathrm{Na}, \mathrm{K}, \mathrm{Mg}, \mathrm{Cl}, \mathrm{SO}_{4}$ and $\mathrm{Si}$ (Table 1; mean concentrations increased 10.9, 0.89, 1.9, 16.1, 2.7 and $0.12 \mathrm{mg} \mathrm{L}^{-1}$, respectively) while flowing through this tunnel (Fig. 4). Surprisingly, effluent water was found to have slightly lower (on average) concentration of $\mathrm{Ca}$ (mean concentration decreased by $3.17 \mathrm{mg} \mathrm{L}^{-1}$ ) than influent water to the tunnel (Fig. 4). With respect to inorganic nutrients, waters flowing out of the tunnel were found to have significantly higher concentrations of $\mathrm{NO}_{3}$ and $\mathrm{PO}_{4}$ (mean concentrations increased by 98 and $13 \mu \mathrm{g} \mathrm{L}^{-1}$ of $\mathrm{N}$ and $\mathrm{P}$ ), and lower, but not significantly different, concentrations of $\mathrm{NH}_{4}$ (mean concentrations decreased by $3 \mu \mathrm{g} \mathrm{L}-1$ of N; Fig. 5). Hence, this par-

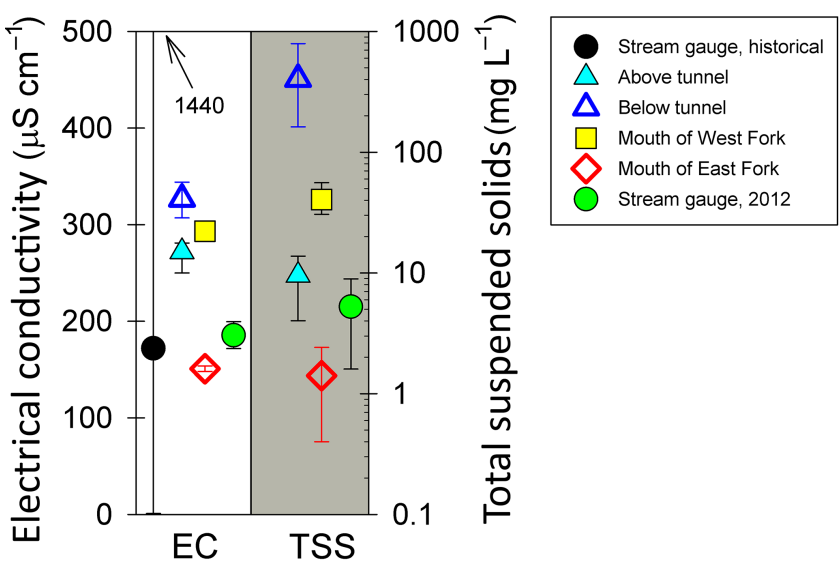

Figure 3. Stream-water electrical conductivity and total suspended solids (note log-scale axis) from historic data collected at stream gauge, above and below the thermokarst tunnel, observed at the mouths of the West and East Forks of Crescent Stream (just above their confluence), and at the stream gauge site in January 2012. See Fig. $3 \mathrm{c}$ for sampling location map. There are no historic TSS data available from Crescent Stream gauge.

ticular tunnel feature was a substantial source of TSS, some weathering solutes, and nutrients to water flowing through it.

\subsection{Comparing East Fork (reference) and West Fork (impacted)}

At a broader spatial scale, comparisons of water chemistry between the East and West Forks of Crescent Stream provide an opportunity to assess the cumulative differences of the impacts of thermokarst development on the West Fork and the reference (no-impact) condition of the East Fork. We fully recognize that this is not as powerful as comparing before and after stream chemistry results from the West Fork. Because the pre-disturbance water chemistry data for the West Fork do not exist, we propose that this comparison is useful for characterizing the impact of these channel changes to the water quality of the West Fork.

West Fork stream water had higher EC and TSS than East Fork stream water (differences in means of $142 \mu \mathrm{S} \mathrm{cm}^{-1}$, and $39.1 \mathrm{mg} \mathrm{L}^{-1}$, respectively) in the days soon after the discovery of the extensive permafrost degradation in January 2012 (Fig. 3). West Fork stream water also had higher concentrations of $\mathrm{Na}, \mathrm{K}, \mathrm{Cl}$, and $\mathrm{SO}_{4}$ than East Fork stream water (mean concentrations were 19.4, 2.97, 28.6 and $9.3 \mathrm{mg} \mathrm{L}^{-1}$ greater, respectively; Fig. 4). However, West Fork stream water was found to have similar concentrations of $\mathrm{Ca}$ and $\mathrm{Si}$ compared to the East Fork stream water (mean concentrations of $\mathrm{Ca}$ were 24.2 and $23.3 \mathrm{mg} \mathrm{L}^{-1}$ in the West Fork and East Fork respectively; while mean $\mathrm{Si}$ concentrations were 3.49 and $3.63 \mathrm{mg} \mathrm{L}^{-1}$ in the West Fork and East Fork, respectively, Fig. 4). With respect to inorganic nutrients, West Fork stream water concentrations were higher than East 
Table 1. Means and standard deviations of water chemistry parameters as observed in three groups. Comparison significance reports the result of paired $t$ tests and Welch's $t$ test among three groups of data in the following order (* indicates significance with a $p$ value $<0.056)$ : inflow to the thermokarst tunnel vs. the outflow, inflow to the thermokarst tunnel vs. the historic data collected at the gauge location, and outflow of the thermokarst tunnel vs. the historic data collected at the gauge location.

\begin{tabular}{|c|c|c|c|c|}
\hline \multirow[b]{2}{*}{ Constituent } & \multicolumn{3}{|c|}{ means \pm standard deviations } & \multirow[b]{2}{*}{$\begin{array}{l}\text { Comparison } \\
\text { Significance }\end{array}$} \\
\hline & $\begin{array}{l}\text { Thermokarst } \\
\text { Tunnel inflow }\end{array}$ & $\begin{array}{l}\text { Thermokarst } \\
\text { Tunnel outflow }\end{array}$ & $\begin{array}{r}\text { Historic data } \\
\text { from Stream gauge }\end{array}$ & \\
\hline $\mathrm{Na}$ & $21.9 \pm 0.34$ & $32.8 \pm 1.23$ & $9.64 \pm 3.30$ & $*, *, *$ \\
\hline K & $5.06 \pm 0.11$ & $5.94 \pm 0.19$ & $2.85 \pm 0.51$ & $*, *, *$ \\
\hline $\mathrm{Ca}$ & $24.7 \pm 0.26$ & $21.5 \pm 1.02$ & $24.4 \pm 4.03$ & $*,-, *$ \\
\hline $\mathrm{Cl}$ & $31.4 \pm 0.63$ & $47.3 \pm 2.18$ & $14.8 \pm 6.94$ & $*, *, *$ \\
\hline $\mathrm{SO}_{4}$ & $12.0 \pm 0.14$ & $14.7 \pm 0.17$ & $6.12 \pm 2.45$ & $*, *, *$ \\
\hline $\mathrm{Si}$ & $7.31 \pm 0.11$ & $7.53 \pm 0.18$ & $3.55 \pm 0.50$ & $-, *, *$ \\
\hline $\mathrm{NO}_{3}$ & $43.8 \pm 0.83$ & $142 \pm 9.85$ & $21.5 \pm 27.92$ & $*, *, *$ \\
\hline $\mathrm{NH}_{4}$ & $11.6 \pm 4.62$ & $8.39 \pm 0.87$ & $6.88 \pm 5.80$ &,,--- \\
\hline $\mathrm{PO}_{4}$ & $26.8 \pm 0.81$ & $40.2 \pm 1.78$ & $13.0 \pm 6.34$ & $*, *, *$ \\
\hline $\mathrm{EC}$ & $272 \pm 12.47$ & $327 \pm 12.32$ & $180 \pm 51.06$ & $*, *, *$ \\
\hline
\end{tabular}

Fork for all three nutrients analyzed: $\mathrm{NO}_{3}, \mathrm{NH}_{4}$, and $\mathrm{PO}_{4}$ (mean concentrations were 63,3 , and $26 \mu \mathrm{g} \mathrm{L}-1$ of $\mathrm{N}$ and $\mathrm{P}$ greater, respectively; Fig. 5). Hence, the cumulative impact of permafrost degradation on the West Fork resulted in much higher TSS, major ion, and nutrient concentrations.

In most cases the mean concentrations of the water flowing out of the thermokarst tunnel were greater than those at the mouth of the West Fork. These differences suggest that the tunnel was a strong modifier of stream water chemistry locally, but is not indicative of the impacts of all thermokarst impact on water chemistry along the $+3 \mathrm{~km}$ of the West Fork impacted. Lower TSS concentrations at the mouth of the West Fork compared to the outflow of the thermokarst tunnel (Fig. 3) could be explained by some combination of sediment deposition and dilution as the thermokarst tunnel water mixes with other stream water in the West Fork channel. The higher EC observed at the outflow of the tunnel compared to the mouth of the West Fork suggests that dilution is partly responsible for the coincident decrease in TSS between these two locations. Whereas calcium and silica concentrations were all very similar $\left(\sim 23\right.$ and $3.5 \mathrm{mg} \mathrm{L}^{-1}$, respectively), $\mathrm{Na}, \mathrm{K}, \mathrm{Cl}$, and $\mathrm{SO}_{4}$ concentrations indicated a dilution signal between the tunnel outflow and the mouth of the West Fork (Fig. 4). Nitrate and $\mathrm{PO}_{4}$ concentrations were also greater in the tunnel outflow than at the mount of the West Fork (Fig. 5), though it is unclear whether this is due to dilution or biological demands of the stream ecosystems (e.g., McKnight et al., 2004).

\subsection{Is thermokarst impacting water chemistry beyond historical ranges?}

Streamflow and chemistry at the Crescent Stream gauge are made up of contributions from the East and West Forks of the stream. Empirically, flows in each channel appear to be

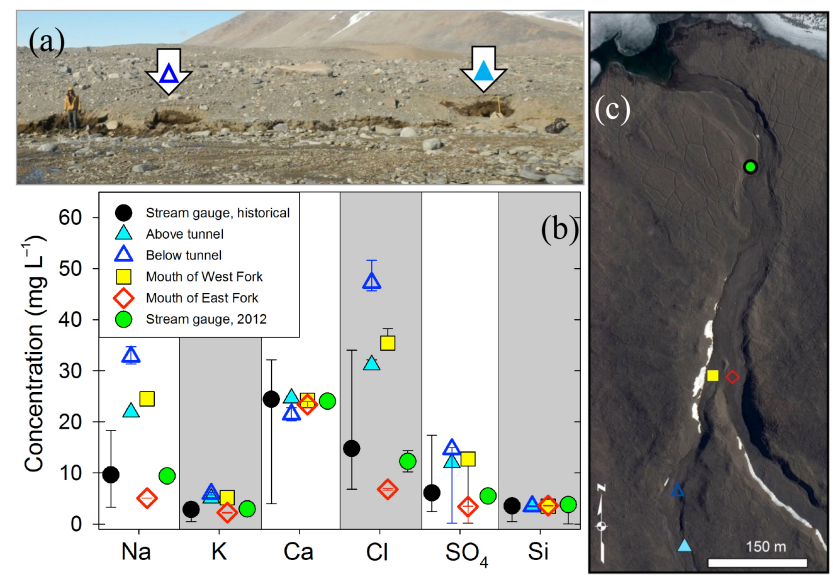

Figure 4. (a) Image of the tunnel that was cut eroded into the eastern bank of the West Fork of Crescent Stream. Flow is from right to left in this image. The cyan (entrance) and blue (exit) arrows correspond to the cyan and blue symbols below. (b) Mean (symbols) and ranges of concentrations of major ions of historical data collected over 15 years at the stream gauge ( $n=47$, except for $\mathrm{Si}$, in which case, $n=46$; downstream-most location), at the stream gauge in 2012 (i.e., after permafrost degradation in banks; $n=2$ ), stream water just above a $20 \mathrm{~m}$ thermokarst tunnel $(n=5)$, stream water just below a $20 \mathrm{~m}$ thermokarst tunnel $(n=5)$, in the West Fork $(n=6)$ and in the East Fork $(n=2)$, just above the location where the West and East Forks mix. (c) Locations of sampling points along Crescent Stream.

comparable though no direct measurements have been made. However, a shift in stream water chemistry at the stream gauge would be evident if concentrations observed at the gauge after the thermokarst development were above the range of concentrations observed historically - over 22 years of data collection. Electrical conductivity is measured every 


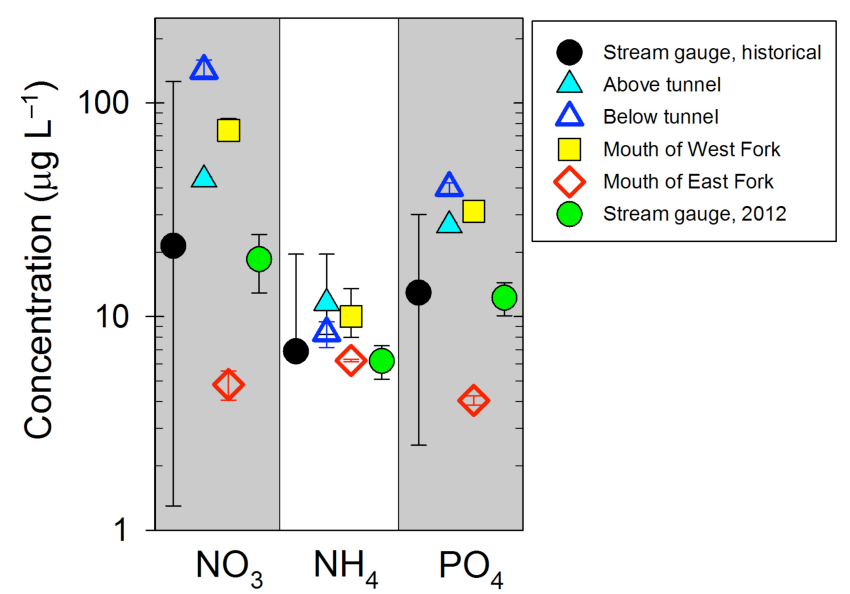

Figure 5. Mean (symbols) and ranges of concentrations of electrical conductivity $(n>5000)$ and major nutrients $(n=47)$ for historical data collected over 15 years at the stream gauge, at the stream gauge in 2012 (i.e., after permafrost degradation in banks; $n=2$ ), stream water just above a $20 \mathrm{~m}$ thermokarst tunnel $(n=5)$, stream water just below a $20 \mathrm{~m}$ thermokarst tunnel $(n=5)$, in the West Fork $(n=6)$ and in the East Fork $(n=2)$, just above the location where the West and East Forks mix. Electrical conductivity is plotted with the scale on the left $y$ axis, while nitrate, ammonium, and phosphate concentrations are indicated on the right $y$ axis (log-scale). Refer to figure $3 \mathrm{C}$ for sampling locations. Concentration are in micrograms per liter of $\mathrm{N}$ or $\mathrm{P}$.

15 min at the stream gauge (starting in December 1991), and these measurements range from 1 to $1440 \mu \mathrm{S} \mathrm{cm}^{-1}$, with a mean of $174 \mu \mathrm{S} \mathrm{cm}^{-1}$ (Fig. 3). After the thermokarst development, EC observed at the stream gauge was elevated compared to the historic mean, but not beyond the historic maximum.

Historically, TSS samples are collected only when very high flows or other abnormal events cause increased turbidity in the streams - any appreciable suspended sediment is notable in MDV streams. In the case of Crescent stream, there are no historic TSS measurements. For most of the major ions $\left(\mathrm{Na}, \mathrm{K}, \mathrm{Ca}, \mathrm{Cl}\right.$, and $\left.\mathrm{SO}_{4}\right), \mathrm{Si}$, and nutrients, stream gauge concentrations were observed to be similar to the means and within the historic ranges of observed concentrations (Fig. 5). However, the ion, $\mathrm{Si}$, and nutrient concentrations of samples collected from the outflow of the thermokarst tunnel were significantly higher than the historic means (Table 1). Thus, while the thermokarst had little downstream influence on solute concentrations, local impacts were substantial. These results suggest that impacts to stream chemistry may be substantial in the event of future larger-scale thermokarst development or if such development occurs along streams without substantial dilution from tributaries.

\section{Discussion}

\subsection{Implications for stream ecosystems}

The MDV make up $<0.3 \%$ of Antarctica, $\sim 4500 \mathrm{~km}^{2}$ (Levy, 2013). While this is a small fraction of the total continent, documenting these changes is important and relevant for a variety of reasons. First of all, due to their limited size and isolated nature, the McMurdo Dry Valleys (MDV) harbor unique endemic microbial communities in stream, lake, and soil habitats (Stanish et al., 2011; Van Horn et al., 2013) and due to the cold, dry climate, this area is the best Martian analog on earth. Thus climate related changes, such as thermokarst development described here, impact our ability to study these extremophiles under the conditions in which they have evolved and thus documenting these changes is vital for future work in this region. The MDV are also sentinels for change in the rest of Western Antarctica (Fountain et al., 2014). The thermokarst described in this study caused a highly observable change in Crescent Stream that was easily noted by researchers. These changes suggest that other climate warming related changes are likely to occur in nearby ice-covered areas where change is less obvious.

The glacial meltwater streams of the MDV are generally clear and do not often transport significant, obvious sediment quantities, with the exception of high flow events. The impact to Crescent Stream was along $\sim 3 \mathrm{~km}$ of stream length, which is $\sim 7 \%$ of the length of the monitored streams in Taylor Valley (43.4 km total, from Conovitz et al., 1998; adding $3 \mathrm{~km}$ for the East Fork of Crescent Stream). Given the cold environment, glacial meltwater pathways are generally supraglacial rather than subglacial, so there is no fluvial erosion of sediment prior to discharge off of the glacier. The stream channels tend to be very stable in general - the McMurdo LTER research teams have not documented degradation of these channels in over 20 years of field research on these streams. Contributing to this stability is the desert pavement that forms along the streambeds, with coarse material having been rotated through numerous freeze-thaw events to yield fairly flat surfaces (McKnight et al., 1999, 2007). Where these stable streambed substrates are found, it is common to find extensive algal mats, compared to channel locations with finer or less stable substrates. Hence, the introduction of fine sediments from streambank erosion is a significant influence to these stream channels that merits attention as it may be a significant ecological disturbance. It is certainly likely that this sort of degradation is not uncommon in the geologic history of these channels, despite having not been observed in the past +20 years, a period during which algal mat communities could have been flourishing in the general absence of the sediment impacts. In many places channels are generally over-sized, trapezoidal incisions into the landscape (on the order of 10 wide and $2 \mathrm{~m}$ deep) with the wetted portion of the channel occupying only a fraction of this width $(3-5 \mathrm{~m})$ and typically shallow $(<0.25 \mathrm{~m})$. Chan- 
nels may well become widened by selective thermomechanical erosion along the margins.

One impact of the thermokarst features on stream ecosystems would be burial of the microbial mats which may be buried by sediments in the reach immediately below the thermokarst features, especially if the flows are low. Our observations along the channel in January 2012 indicate that a lot of fine sediment has been dispersed throughout the channel, and also indicate very little occurrence of algal mats. Stream discharge is quite cyclical in these streams. On a daily basis there is a flood pulse from enhanced glacier melt due to solar aspect, and across the season, streams generally start and end with fairly low flows and experience much higher flows in between. While the flow magnitude variability is unpredictable, the daily and seasonal pulses of stream flow are likely to transport deposited sediment through the next several years. The timescale of this legacy is not clear. Whether mats are likely to scour may also depend on how substantial the mats are (how extensive they are and how well they are attached to substrate), the magnitude of the flows during diurnal and seasonal cycles, and the extent to which mats can grow during low-flow (non-scour) conditions.

The substantial introduction of fine sediment associated with these thermokarst features can be expected to have some influence of stream ecosystem function also at high flows. Analysis of the long-term record indicates that scour at high flows constrains the biomass of microbial mats (Stanish et al., 2011; Kohler et al., 2015a). Kohler et al. (2015b) specifically focused on epilithon responses from scour events, noting that recovery times were generally weeks to months, potentially longer than a single flow season. Furthermore, Cullis et al. (2014) showed that the daily transport of particulate organic matter (POM) from sloughing driven by fluvial shear stress was limited by the availability of "mobile biomass" associated with the mats. However, at high flow the hysteretic pattern associated with such a limitation was not observed and direct scour of the mats appeared to be the dominant mechanism controlling POM transport. If there is more abundant fine sediment in the channel, the magnitude of flow required for a "re-setting" scouring event may be lower, e.g. potentially lower than the $100 \mathrm{~L} \mathrm{~s}^{-1}$ threshold used by Cullis et al. (2014) in their model. The lower limit for a re-setting flow may be determined by the flow required to keep introduced sediment entrained in the reaches where the microbial mats thrive.

Previous studies of nutrient uptake in these streams indicate that both the microbial mats in the channel and the hyporheic zone that occupies the sediments adjacent to the channels are important locations of uptake and processing (Gooseff et al., 2004; McKnight et al., 2004). In the water column, the reduction of algal mats due to either burial or scour would reduce the opportunity for biogeochemical processing of nutrients as these streams act as a filter of nutrients to the endorheic lakes at their termini. However, burial of algal mats may well fuel hyporheic biogeochemical cycling as the increased organic matter in the subsurface may help to stimulate microbiological transformation of nutrients that exchange through these sediments (Schindler and Krabbenhoft, 1998).

While substantial changes in major ion concentrations along a $\sim 10 \mathrm{~m}$ thermokarst tunnel flow path are not necessarily indicative of all instances of contact of stream water with degraded banks, the changes (Figs. 4 and 5) do indicate a strong potential for changes in water quality over very short distances. Thus, there is a strong potential for stream ecosystem impacts from even isolated degradation features. The observed elevated nutrient concentrations in waters affected by thermokarst may be a positive response that could counter the effects of algal mat removal or burial. The source of nitrate to MDV streams is atmospheric deposition, mostly from glacial sources (Downes et al., 1986; Howard-Williams et al., 1989), and phosphate is generally sourced from chemical weathering (Howard-Williams et al., 1989). Increasing the concentrations of these nutrients in stream waters may stimulate increased algal growth and therefore re-establishment of algal mat coverage.

It is surprising that the weathering solutes do not show a stronger response in the stream water downstream of the permafrost degradation. Weathering rates of the streambed materials in the MDVs has been reported to be among the highest in the world despite the cold temperatures (Lyons et al., 1997; Gooseff et al., 2002). The increase in major ion concentrations observed reflects a mobilization of readily soluble salts such as $\mathrm{NaCl}$ rather than an increase in chemical weathering ( $\mathrm{Si}$ and $\mathrm{Ca}$ ).

It is not yet clear how long the degradation will occur, and how long the fine sediment deposits in the stream channel and the elevated major ion and nutrient concentrations will persist in the West Fork of Crescent Stream. The degraded banks of the channel will slowly modify through annual and seasonal freeze-thaw cycles and associated slow cryoturbation, potentially "healing" the stark eroded surfaces observed in January 2012. Winter snow may accumulate in some of the new hollows insulating and stabilizing the banks. During the austral summer, a positive surface energy balance may cause further permafrost thaw and continued thermomechanical erosion. The channel will continue to respond to hydrology that is dynamic on several timescales (daily pulses of melt water; high and/or low flow seasons). As it does, the degraded sections of the channel may further erode due to shear stress associated with high flows. The fine sediment introduced by the thermokarst formation and algal communities in the channel will also respond, with high flows potentially moving the sediment further downstream and potentially scouring algal mats that are trying to re-establish and grow, and low flows promoting the persistence of fine sediment deposits and algal growth. Recent findings by Cozzetto et al. (2013) indicate that the hyporheic zones of MDV streams have a wide range of exchange timescales, some very short, and some long (Gooseff et al., 2003), and therefore 
strong heterogeneity in sediment size and hydraulic conductivity distributions likely exist in MDV streambeds.

\subsection{Implications for endorheic lakes}

The MDV endorheic lakes integrate all stream inputs and processes that affect streamflow generation. Foreman et al. (2004) found that during the very high-flow season of 2001-2002, the introduction of fine sediment from primarily a single second-order sand-bed stream all of the streams to the East Lobe of Lake Bonney reduced the incoming photosynthetically active radiation (PAR), which decreased the chlorophyll $a$ concentrations in the water column. In the case of the degradation on the West Fork of Crescent Stream, a lot of fine sediment has been moved from the channel banks into the streambed and some of this has been transported downstream. Empirical evidence of deposition of these fines downstream exists, and presumably some of it was delivered to Lake Fryxell. However, given that Crescent Stream is one of over a dozen streams contributing to Lake Fryxell, it is not likely that this event had a strong influence on the suspended sediment of the lake water column. The elevated concentrations of solutes, particularly nutrients, may have a more substantial impact on moats or main water column of Lake Fryxell. Again, however, the elevated input from a single stream is likely not particularly significant from this event. Should the occurrence of permafrost degradation along streams in the MDVs become more common, the lake ecosystems will likely respond to increased nutrients and fine sediment in the water column (reducing radiation transmission through the water column). The legacy of these impacts in lakes may be on the timescale of a year or so as suspended sediment will settle out of the water column during the winter and increased nutrients may lead to increased uptake. Repeated fluxes of increased sediment and nutrients annually due to permafrost degradation and high enough flows to mobilize sediment to the lakes may provide substantial impacts to lake ecosystems over several years.

\section{Conclusions}

Extensive permafrost degradation on the banks of the West Fork of Crescent Stream in the McMurdo Dry Valleys, Antarctica has resulted in substantial input of fine sediment to the stream and increased solute concentrations, particularly nitrate. These streams have not been observed to experience large pulses of fine sediment except during very high flow events. This input of sediment related to permafrost degradation has the potential to bury and/or scour stream algal mats and provide turbidity to endorheic lake water columns. Increased nutrient concentrations are likely to promote algal mat re-establishment and growth. This pulse disturbance to this aquatic ecosystem may have persistent (several flow seasons) impacts to the channel as typical flows are fairly low and it may take years to flush the introduced sediment.

Acknowledgements. This research was funded by McMurdo LTER NSF OPP grant 1115245 (to MNG, DMM, and WBL). Additional support was provided by PLR 1246203 (to MNG) and 1245991 (to DVH). The authors wish to acknowledge Raytheon Polar Services Company, UNAVCO, and Petroleum Helicopters, Inc. for field support.

Edited by: J. Vonk

\section{References}

Bekryaev, R. V., Polyakov, I. V., and Alexeev, V. A.: Role of polar amplification in long-term surface air temperature variations and modern Arctic warming, J. Climate, 23, 3888-3906, 2010.

Bockheim, J. G.: Permafrost distribution in the southern circumpolar region and its relation to the environment: a review and recommendations for further research, Permafrost Periglac., 6, 27-45, 1995.

Bockheim, J. G., Campbell, I. B., and McLeod, M.: Permafrost distribution and active layer depths in the McMurdo Dry Valleys, Antarctica, Permafrost Periglac., 18, 217-227, 2007.

Bowden, W., Gooseff, M. N., Balser, A., Green, A., Peterson, B. J., and Bradford, J.: Sediment and nutrient delivery from thermokarst features in the foothills of the North Slope, Alaska: Potential impacts on headwater stream ecosystems, J. Geophys. Res.-Biogeo., 113, G02026, doi:10.1029/2007JG000470, 2008.

Chadburn, S. E., Burke, E. J., Essery, R. L. H., Boike, J., Langer, M., Heikenfeld, M., Cox, P. M., and Friedlingstein, P.: Impact of model developments on present and future simulations of permafrost in a global land-surface model, The Cryosphere, 9, 1505-1521, doi:10.5194/tc-9-1505-2015, 2015.

Conovitz, P. A., McKnight, D. M., MacDonald, L. H., and Fountain, A. F.: Hyddrologic processes influencing streamflow variation in Fryxell Basin, Antarctica, in: Ecosystem Processes in a Polar Desert: The McMurdo Dry Valleys, Antarctica, edited by: Priscu, J., American Geophysical Union, 93-108, 1998.

Cozzetto, K. D., Bencala, K. E., Gooseff, M. N., and McKnight, D. M. The influence of stream thermal regimes and preferential flow paths on hyporheic exchange in a glacial meltwater stream, Water Resour. Res., 49, 5552-5569, 2013.

Cullis, J. D. S., Stanish, L. F., and McKnight, D. M.: Diel flow pulses drive particulate organic matter transport from microbial mats in a glacial meltwater stream in the McMurdo Dry Valleys, Water Resour. Res., 50, 86-97, doi:10.1002/2013WR014061, 2014.

Doran, P. T., McKay, C. P., Fountain, A. G., Nylen, T., McKnight, D. M., Jaros, C., and Barrett, J. E.: Hydrologic response to extreme warm and cold summers in the McMurdo Dry Valleys, East Antarctica, Antarct. Sci., 20, 499-509, 2008.

Downes, M. T., Howard-Williams, C., and Vincent, W. F.: Sources of organic nitrogen, phosphorus and carbon in antarctic streams, Hydrobiologia, 134, 215-225, 1986.

Esposito, R. M. M., Horn, S. L., McKnight, D. M., Cox, M. J., Grant, M. C., Spaulding, S. A., Doran, P. T., and Cozzetto, 
K. D.: Antarctic climate cooling and response of diatoms in glacial meltwater streams, Geophys. Res. Lett., 33, L07406, doi:10.1029/2006g1025903, 2006.

Foreman, C. M., Wolf, C. F., and Priscu, J. C.: Impact of episodic warming events on the physical, chemical and biological relationships of lakes in the McMurdo Dry Valleys, Antarctica, Aquat. Geochem., 10, 239-268, 2004.

Fountain, A. G., Levy, J. S., Gooseff, M. N., and Van Horn, D.: The McMurdo Dry Valleys: a landscape on the threshold of change, Geomorphology, 225, 25-35, doi:10.1016/j.geomorph.2014.03.044, 2014.

Gooseff, M. N., McKnight, D. M., Lyons, W. B., and Blum, A. E.: Weathering reactions and hyporheic exchange controls on stream water chemistry in a glacial meltwater stream in the McMurdo Dry Valleys, Water Resour. Res., 38, WR000834, doi:10.1029/2001WR000834, 2002.

Gooseff, M. N., McKnight, D. M., Runkel, R. L., and Vaughn, B. H.: Determining long time-scale hyporheic zone flow paths in Antarctic streams, Hydrol. Process., 17, 1691-1710, 2003.

Gooseff, M. N., McKnight, D. M., Runkel, R. L., and Duff, J. H.: Denitrification and hydrologic transient storage in a glacial meltwater stream, McMurdo Dry Valleys, Antarctica, Limnol. Oceanogr., 49, 1884-1895, 2004.

Green, W. J., Angle, M. P., and Chave, K. E.: The geochemistry of Antarctic streams and their role in the evolution of four lakes of the McMurdo Dry Valleys, Geochim. Cosmochim. Ac., 52, 1265-1274, 1988.

Howard-Williams, C., Priscu, J. C., and Vincent, W. F.: Nitrogen dynamics in two Antarctic streams, Hydrobiologia, 172, 51-61, 1989.

Kohler, T. J., Stanish, L. F., Crisp, S. W., Koch, J. C., Liptzin, D., Baeseman, J. L., and McKnight, D. M.: Life in the main channel: Long-term hydrologic control of microbial mat abundance in McMurdo Dry Valley streams, Antarctica, Ecosystems, 18, 310 327, 2015a.

Kohler, T. J., Chatfield, E., Gooseff, M. N., Barrett, J. E., and McKnight, D. M. Recovery of Antarctic stream ebilithon from simulated scouring events, Antarct. Sci., 27, 341-354, 2015b.

Kokelj, S., Jenkins, R., Milburn, D., Burn, C., and Snow, N.: The influence of thermokarst disturbance on the water quality of small upland lakes, Mackenzie Delta region, Northwest Territories, Canada, Permafrost Periglac., 16, 343-353, 2005.

Kokelj, S., Zajdlik, B., and Thompson, M.: The impacts of thawing permafrost on the chemistry of lakes across the subarctic boreal Äêtundra transition, Mackenzie Delta region, Canada, Permafrost Periglac., 20, 185-199, 2009.

Kokelj, S., Lacelle, D., Lantz, T., Tunnicliffe, J., Malone, L., Clark, I., and Chin, K.: Thawing of massive ground ice in mega slumps drives increases in stream sediment and solute flux across a range of watershed scales, J. Geophys. Res.-Earth, 118, 681-692, 2013.

Lafrenière, M. J. and Lamoureux, S. F.: Thermal perturbation and rainfall runoff have greater impact on seasonal solute loads than physical disturbance of the active layer, Permafrost Periglac., 24, 241-251, 2013.

Lamoureux, S. F. and Lafrenière, M. J.: Fluvial impact of extensive active layer detachments, Cape Bounty, Melville Island, Canada, Arct. Antarct. Alp. Res., 41, 59-68, 2009.

Larouche, J. R., Abbott, B. W., Bowden, W. B., and Jones, J. B.: The role of watershed characteristics, permafrost thaw, and wildfire on dissolved organic carbon biodegradability and water chemistry in Arctic headwater streams, Biogeosciences, 12, 42214233, doi:10.5194/bg-12-4221-2015, 2015.

Levy, J.: How big are the McMurdo Dry Valleys? Estimating icefree area using Landsat image data, Antarct. Sci., 25, 119-120, 2013.

Levy, J. S., Fountain, A. G., Dickson, J. L., Head, J. W., Okal, M., Marchant, D. R., and Watters, J.: Accelerated thermokarst formation in the McMurdo Dry Valleys, Antarctica, Scientific reports, 3, 2013

Lewis, T., Lafrenière, M. J., and Lamoureux, S. F.: Hydrochemical and sedimentary responses of paired High Arctic watersheds to unusual climate and permafrost disturbance, Cape Bounty, Melville Island, Canada, Hydrol. Process., 26, 2003-2018, 2012.

Lyons, W. B., Welch, K. A., Nezat, C. A., Crick, K., Toxey, J. K., Mastrine, J. A., and McKnight, D. M.: Chemical weathering rates and reactions in the Lake Fryxell Basin, Taylor Valley: Comparison to temperate river basins, in: Ecosystem Processes in Antarctic Ice-free Landscapes, edited by: Lyons, W. B., HowardWilliams, C., and Hawes, I., Balkema Press, 1997.

Lyons, W. B., Welch, K. A., Neumann, K., Toxey, J. K., McArthur, R., Williams, C., McKnight, D. M., and Moorhead, D.: Geochemical linkages among glaciers, streams and lakes within the Taylor Valley, Antarctica, 1998.

McKnight, D. M., Niyogi, D. K., Alger, A. S., Bomblies, A., Conovitz, P. A., and Tate, C. M.: Dry Valley Streams in Antarctica: Ecosystems Waiting for Water, Bioscience, 49, 985-995, 1999.

McKnight, D. M., Runkel, R. L., Tate, C. M., Duff, J. H., and Moorhead, D.: Inorganic N and P dynamics of Antarctic glacial meltwater streams as controlled by hyporheic exchange and benthic autotrophic communities, J. N. Am. Bethol. Soc., 23, 171-188, 2004.

McKnight, D. M., Tate, C. M., Andrews, E. D., Niyogi, D. K., Cozzetto, K., Welch, K., Lyons, W. B., and Capone, D. G.: Reactivation of a cryptobiotic stream ecosystem in the McMurdo Dry Valleys, Antarctica: A long-term geomorphological experiment, Geomorphology, 89, 186-204, 2007.

Northcott, M. L., Gooseff, M. N., Barrett, J. E., Zeglin, L. H., Takacs-Vesbach, C. D., and Humphrey, J.: Hydrologic characteristics of lake- and stream-side riparian wetted margins in the McMurdo Dry Valleys, Antarctica, Hydrol. Process, 23, 12551267, 2009.

R Development Core Team: R: A language and environment for statistical computing. R Foundation for Statistical Computing, Vienna, Austria, 2011.

Runkel, R. L., McKnight, D. M., and Andrews, E. D.: Analysis of transient storage subject to unsteady flow: diel flow variation in an Antarctic stream, J. N. Am. Bethol. Soc., 17, 143-154, 1998.

Schindler, J. E. and Krabbenhoft, D. P.: The hyporheic zone as a source of dissolved organic carbon and carbon gases to a temperate forested stream, Biogeochemistry, 43, 157-174, 1998.

Serreze, M. C. and Barry, R. G.: Processes and impacts of Arctic amplification: A research synthesis, Global Planet. Change, 77, 85-96, 2011a.

Serreze, M. C. and Barry, R. G.: Processes and impacts of Arctic amplification: A research synthesis, Global Planet. Change, 77, 85-96, 2011b. 
Shaw, J. and Healy, T. R.: The formation of the Labyrinth, Wright Valley, Antarctica, New Zeal. J. Geol. Geop., 20, 933-947, 1977.

Stanish, L. F., Nemergut, D. R., and McKnight, D. M.: Hydrologic processes influence diatom community composition in Dry Valley streams, J. N. Am. Bethol. Soc., 30, 1057-1073, 2011.

Stanish, L., O’Neill, S., Gonzalez, A., Bilinski, T., Knelman, J., McKnight, D. M., Spaulding, S. A., and Nemergut, D. R.: Bacteria and diatom co-occurrence patterns in microbial mats from polar desert streams, Environ. Microbiol., 15, 1115-1131, doi:10.1111/j.1462-2920.2012.02872.x, 2013.
Swanger, K. M. and Marchant, D. R.: Sensitivity of ice-cemented Antarctic soils to greenhouse-induced thawing: Are terrestrial archives at risk?, Earth Planet. Sci. Lett., 259, 347-359, 2007.

Welch, K. A., Lyons, W. B., Whisner, C., Garnder, C. B., Gooseff, M. N., McKnight, D. M., and Priscu, J. C.: Spatial variations in the geochemistry of glacial meltwater streams in the Taylor Valley, Antarctica, Antarct. Sci., 22, 662-672, 2010. 